\title{
Functional Food: A Growing Trend among the Health Conscious
}

\author{
Teck-Chai Lau ${ }^{1}$, Mei-Wan Chan ${ }^{1}$, Hoi-Piew $\operatorname{Tan}^{1} \&$ Choon-Ling Kwek ${ }^{2}$ \\ ${ }^{1}$ Faculty of Accountancy and Management, Universiti Tunku Abdul Rahman, Bandar Sungai Long, Malaysia \\ ${ }^{2}$ Faculty of Business and Information Science, UCSI University, Kuala Lumpur, Malaysia \\ Correspondence: Teck-Chai Lau, Faculty of Accountancy and Management, Universiti Tunku Abdul Rahman, \\ Sungai Long Campus, Lot PT 21144, Jalan Sungai Long, Bandar Sungai Long, Cheras, 43000 Kajang, Selangor, \\ Malaysia. Tel: 60-16-391-7684. E-mail: lautc@utar.edu.my
}

Received: September 29, 2012 Accepted: October 27, 2012 Online Published: December 31, 2012

doi:10.5539/ass.v9n1p198 URL: http://dx.doi.org/10.5539/ass.v9n1p198

\begin{abstract}
Food can do far more than filling humans' stomach: they can promote and protect our health. Some food contains bioactive components that are beneficial to health and are able to reduce risks of chronic diseases. These foods are known as "functional foods". The interest in functional foods has increased in developed economies as people look for safer way to improve general health and living. Not much is known about acceptance of functional foods among Malaysian consumers. The aim of this paper is to review the definition and regulatory bodies governing functional food across different countries. This will be followed by an overview of the functional food growth potential in Malaysia and a discussion on factors that might influence the purchase of functional food.
\end{abstract}

Keywords: functional food, health conscious, health benefits, consumers, Malaysia

\section{Introducation}

With the rapid socio-economic growth Malaysia experiences over the decades, modern living brings about changes and health issues such as heart disease, cancer, and diabetes to various segments of the population. Realising the seriousness of this problem, government policies supporting healthy living and preventive measures against illnesses are often introduced and reinforce. As more Malaysians are exposed to various health threats, the demands for health enhancing foods are growing. The increased health concerns among Malaysians have made available more health-promoting products in the market. A better informed Malaysians have been the driver of the increased purchase of functional foods, nutraceuticals and organic foods (Stanton, Emms \& Sia, 2011).

Functional foods are foods that may provide health benefits beyond basic nutrition (Bech-Larsen \& Grunert, 2003). This simple definition is also in accordance with the major selling proposition for functional foods, where functional foods enable the consumer to lead a healthier life without changing eating habits (Jonas \& Beckmann, 1998). The potential for functional foods are promising, as consumer generally wants to buy healthy food (Brunsø, Grunert, \& Bredahl, 1996), but at the same time reluctant to change their eating habits, even when what they are eating currently are known to be unhealthy (Williamson, Hunt, Pope, \& Tolman, 2000).

Functional foods are not pills, and it remains in the form of food and are part of the normal food pattern (Diplock et al., 1999). Nutraceutical or health supplements are not associated with foods because the bioactive components have been isolated and presented to consumers in medicinal forms such as capsules and tablets (Tee, 2011). The idea of maintaining a healthy and nutritious lifestyle and diet is well incorporated in the minds of most Malaysians. Generally, the foundation for health and wellness are already established among Malaysians. Most have some knowledge of traditional wellness and herbal medicines, usually passed down through generations. Malaysians in general have experience traditional functional foods in some stage of their lives.

Modern functional foods available to Malaysian consumers are produced by major multinational food producers and some local manufacturers, and distributed through modern trades. Most of the functional foods appear in the form of conventional foods. Functional foods are not a well-defined food category (Niva \& Mäkelä, 2005). As a result, convergence is observed in the functional foods and conventional foods segment; and at industry level, nutraceuticals and foods sectors (Broring, Cloutier, \& Leker, 2006). 
Previous studies on functional food are mostly from developed countries and differences exist between the Western and Asian consumers. The aim of this paper is to provide a clear view of functional food and its concept and how it is perceived in other countries as well as in Malaysia. The objective of this paper is to review the definition and regulatory bodies governing functional food across countries. This will be followed by an overview of the functional food growth potential in Malaysia and a discussion on factors that might influence the purchase of functional food.

\section{Definitions of Functional Food}

The term "functional food" started in Japan during the eighties, for food products fortified with special ingredients that provide physiological benefits. Later, the concept of functional food was accepted in countries such as the US, Canada, Europe as well as other parts of the world. There is no unitary accepted definition of functional foods globally, although several definitions have been proposed (Tee, 2007; Alzamora, et al., 2005). The term "functional food" varies across countries. National authorities, academicians and food industry specialists generally understood functional foods to contain bioactive components or fortified with nutrients to provide health benefits beyond basic nutrients, similar in appearance to conventional food and intended to be consumed as part of daily diet (Tee, 2007; Bech-Larsen \& Grunert, 2003). The definitions of functional food have been compiled in accordance to countries and national authorities and are shown in Appendix 1.

Most countries describe functional foods to contain bioactive components and ingredients that provide additional health benefits beyond basic requirements and capable of reducing certain diseases. The appearance of functional foods may be in the form of natural food or conventional food and consumed as part of daily diets. According to Siro' et al., 2008, functional food is considered a concept by the European legislation instead a specific food category. Australia and New Zealand authorities categorised functional food as novel food.

As to date, no country in the world currently uses the term "functional food" in its regulation (Tee, 2007). Furthermore, FAO/WHO Codex Alimentarius System does not provide clear guidelines or specifications for functional foods (CODEX Alimentarius, 2011). Due to its ambiguous nature, functional foods are rigorously accessed by national authorities. The regulatory bodies developing policies and governing regulations for foods in various countries are listed in Table 1.

Table 1. Regulatory bodies governing nutrition health claims in various countries

\begin{tabular}{ll}
\hline Country & Regulatory Body \\
\hline Australia and New Zealand & Food Standards Australia New Zealand \\
Brazil & National Health Surveillance Agency \\
Canada & Health Canada \\
China & State Food and Drug Administration \\
European Union & European Food Safety Authority \\
France & French Food Safety Agency \\
Japan & Ministry of Health, Labour and Welfare \\
The Netherlands & Netherlands Nutrition Centre \\
Sweden & Swedish Nutrition Foundation \\
United Kingdom & Joint Health Claims Initiative \\
USA & Food and Drug Administration \\
\hline
\end{tabular}

Source: Jew et al. (2008)

\section{Overview of Regulatory Environment in Asia and Malaysia}

Currently, official definition and specific regulations are unavailable for functional food products in Malaysia, Singapore, Thailand, Indonesia, Myanmar or Vietnam (Tee, 2007). Functional foods in these countries are usually regulated under conventional foods category, distinct from nutraceuticals regulations. For South Korea and Philippines, "functional food" includes dietary supplements (Tee, 2007). Countries such as Japan, China, South Korea and Taiwan have developed national regulations for functional foods or health promoting products. Food products that claim health functions must be reviewed by authority and registered in the strictest adherence prior to their release into the market. In Japan, functional foods are regulated under the "Food for Specified Health Uses" or FOSHU system, China by the Ministry of Health, South Korea by the Korean Food and Drug 
Administration (Kim et al., 2006), and Taiwan under the Health Food Control Act 1999 (Tee, 2007).

In Malaysia, all food, drinks and food ingredients imported or manufactured locally are required to comply with the Malaysian food regulation (Stanton et al., 2011). The key laws and regulations in Malaysia for food are:

1) Food Act 1983 and Food Regulation 1985,

2) Control of Drugs and Cosmetics Regulation 1984,

3) Halal laws and regulations.

The main government department and agencies in Malaysia that implement and enforce these regulations are:

1) Food Safety and Quality Division (FSQD),

2) Drug Control Authority (DCA), provides the general principles of safety, quality and efficacy that form the basis for the evaluation and eventual registration of products,

3) National Pharmaceutical Control Bureau (NPCB),

4) Committee for the Classification of Food-Drug Interface Products, involves in functional foods and drinks, and nutraceuticals,

5) Malaysian National Codex Committee; Malaysia regulations are developed based on CODEX, a legal systems in other part of the world (usually the Developed World),

6) Jabatan Kemajuan Islam Malaysia (JAKIM), the Malaysian national halal certification agency.

\section{Regulations Covering Functional Foods and Drinks in Malaysia}

In Malaysia, there is no official definition for functional foods (Stanton et al., 2011; Tee, 2007; Arshad, 2002). According to the Drug Control Authority, the product is considered a food product if it contains $80 \%$ or more food ingredients either single or in combination, with equal to or less than $20 \%$ of biologically active ingredients of natural products with pharmacological and/or therapeutic properties.

Due to the complex nature of nutraceuticals and its links to medicines, nutraceutical products can be defined as either food or drugs, depending on its nature, characteristics and effects on consumers (Stanton et al., 2011). As a result, functional foods can be considered nutraceutical products in Malaysia due to its ambiguous nature. Thus, the Committee for the Classification of Food-Drug Interface Products provides official guidelines to determine whether a product is a food or a drug (National Pharmaceutical Control Bureau, 2012). The guidelines are complex and detailed, and the important ones are extracted to distinguish between a nutraceutical and functional food product (Ministry of Health, 2012).

They are as follow:

1) The product is regarded as food products if a product contains $80 \%$ or more of food ingredients, either single or in combination, and with equal to or less than $20 \%$ of biologically active ingredients of natural products with pharmacological and/or therapeutic properties, and has to be regulated by Food Safety and Quality Division (FSQD). Eg many types of functional foods.

2) If a product contains less than $80 \%$ of food-based ingredients and more than $20 \%$ of the active ingredients, such product should be regulated by National Pharmaceutical Control Bureau (NPCB). Notwithstanding this general rules, for products containing specific ingredients which possess high potencies, even if they contain less than $20 \%$ active ingredients, they shall be reviewed by the Committee and may be regulated by NPCB as a form of drug (National Pharmaceutical Control Bureau, 2012).

When uncertainty arises about the effectiveness and safety of a product, NPCB would be the preferred authority to regulate. If a product is more than $80 \%$ food-based, and contains active ingredients that exceed the amount permitted in the Food Regulations 1985, the manufacturer shall be advised to reduce the amount of functional ingredients and to be regulated by FSQD (Ministry of Health, 2012; Stanton et al., 2011).

\section{Types of Functional Foods}

The key types of functional foods are fortified, enriched, altered and enhanced products (Siro' et al., 2008) and are listed in Table 2. Early developments of functional foods were those fortified with vitamins and/or minerals such as vitamin E, vitamin C, folic acid, zinc, iron and calcium (Sloan, 2000). At later stage, foods were fortified with macronutrients such as soluble fibre and omega-3 fatty acid to promote food health or to prevent diseases such as cancers (Sloan, 2002). 
Table 2. Prominent types of functional food

\begin{tabular}{|c|c|c|}
\hline Types of Functional Food & Definition & Example \\
\hline Fortified products & A food fortified with additional nutrients & $\begin{array}{l}\text { Fruit juices } \mathrm{fc} \\
\text { Vitamin } \mathrm{C}\end{array}$ \\
\hline Enriched products & $\begin{array}{l}\text { A food with added new nutrients or } \\
\text { components not normally found in a particular } \\
\text { food }\end{array}$ & $\begin{array}{l}\text { ed new nutrients or Margarine with plant sterol } \\
\text { ally found in a particular ester, probiotics, prebiotics }\end{array}$ \\
\hline Altered products & $\begin{array}{l}\text { A food from which a deleterious component } \\
\text { has been removed, reduced or replaced with } \\
\text { another substance with beneficial effects }\end{array}$ & $\begin{array}{l}\text { deleterious component } \\
\text { duced or replaced with } \\
\text { beneficial effects }\end{array}$ \\
\hline Non-altered products & $\begin{array}{l}\text { Foods naturally containing increased content } \\
\text { of nutrients or components }\end{array}$ & $\begin{array}{l}\text { iining increased content Natural foods } \\
\text { hents }\end{array}$ \\
\hline Enhanced products & $\begin{array}{l}\text { A food which one of the component has been } \\
\text { naturally enhanced through special growing } \\
\text { conditions, new feed composition, genetic } \\
\text { manipulation or otherwise. }\end{array}$ & 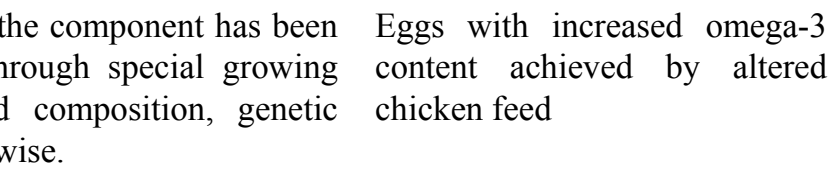 \\
\hline \multicolumn{3}{|c|}{ Source: Siro'et al (2008) and Agri-food Trade Service (2009) } \\
\hline \multirow{2}{*}{\multicolumn{3}{|c|}{$\begin{array}{l}\text { There are many components in food that are believed to provide health benefits. Some main group of functional } \\
\text { ingredients include carotenoids, lypopene, dietary fibres, flavonoids, and probiotics. The popular components are } \\
\text { listed in Table } 3 \text {. } \\
\text { Table 3. Potential benefits of food components }\end{array}$}} \\
\hline & & \\
\hline Components & Product & Potential Benefits \\
\hline Lycopene & Tomato products & Reduce the risk of prostate cancer \\
\hline Beta-glucan & Oats, barley & $\begin{array}{l}\text { Reduce cardiovascular disease, lower LDL, and total } \\
\text { cholesterol risks }\end{array}$ \\
\hline $\begin{array}{l}\text { Omega-3 Fatty Acids - } \\
\text { DHA/EPA }\end{array}$ & Fish oils & $\begin{array}{l}\text { Reduce cardiovascular disease, and improve mental } \\
\text { functions }\end{array}$ \\
\hline Catechins & Tea & Neutralize fere radicals and reduce cancer risks \\
\hline Isoflavones & Soy-based products & $\begin{array}{l}\text { Reduce cardiovascular disease, lower LDL, and total } \\
\text { cholesterol risks }\end{array}$ \\
\hline Flavones & Flax seed & Neutralize free radicals and reduce cancer risks \\
\hline Lactobacillus & Yoghurt & Improve quality of intestinal microflora \\
\hline
\end{tabular}

Source: Agri-food Trade Service (2009)

\section{The Market of Functional Foods}

Functional food products are non-homogeneous food category; it is expanded to all segments of the food and drink market (Siro' et al., 2008). Functional foods are predominantly found in the dairy, confectionery, soft drinks, bakery and baby food market (Menrad, 2003). The markets for functional food are very large and growing steadily worldwide, intensely competitive and many new products are launched continuously. From a report entitled "Consumer Trends: Functional Foods" released by Agri-Food Trade Service in 2009, researchers state the annual growth rate for functional foods are about $8 \%$ to $14 \%$, but the exact size is difficult to measure, and the global market size is estimated from USD7 billion to USD167 billion.

The functional food industry is resource-intensive, in terms of financial and time requirement for basic research, technology development and commercialization, including obtaining product approvals, and marketing strategy (Hobbs, 2002) and is often shifted by economic conditions. Many health-promoting ingredients are still being tested for long-term effects or facing discrepancies to scientific opinions (Agri-Food Trade Service, 2009). The complexity of functional food industry leads to formation of new supply chain partnerships among suppliers, farmers, researchers and food manufacturers. Opportunities for joint ventures or strategic alliances emerge and supply of functional ingredients through contracts and special supply arrangements are needed (Agri-Food Trade Service, 2009). 
Due to the attractiveness of functional foods, this industry is highly concentrated and dominated by large companies. It is often perceived by stakeholders that functional foods could improve margins, provide untapped market and attract customer loyalty. However, it is also generally characterised by high rate of failure for new products, often due to insufficient market research, and consumers' complexity and market conditions. The challenges facing functional foods are the development, marketing and consumers. These are high cost of marketing which often exceed product development costs, low consumer awareness of health effects and knowledge of newly developed functional ingredients, and regulatory barriers (Menrad, 2003).

Consumer surveys and other market studies in the US and Europe indicate the general success factors for marketing of conventional foods are valid for functional foods (Bech-Larsen \& Grunert, 2003; Poulsen, 1999; Childs \& Poryzees, 1997). These factors are tasty products, convenience, product variety and different packaging volumes. Menrad (2003) also cites that functional ingredients are regarded as added value, but do not determines the choice of products by itself, thus the base-product for functional foods should convey healthy image and avoid medical or clinical perspective. Although functional foods possess unique nutritional characteristics and health benefits, functional foods still compete with conventional foods for market share and shelf space in retails (Hobbs, 2002).

\section{Market Size, Structure and Development Trends in Malaysia}

The general food and beverage market in Malaysia is estimated at RM30 billion (Stanton et al., 2011). Due to lack of information available for functional foods in Malaysia, it can be assumed that Malaysia has an attractive functional food and beverage niche from its large food and beverage market. Trade sources estimated functional foods consist about 40 per cent of total processed and retail packed food and drinks markets (Stanton et al., 2011).

The significant segments include infant and other milk formulas, dairy-based drinks, energy drinks, sport drinks, fruit juices, drinks with Asian herbs, cereals, energy bars, biscuits, baked products, and eggs with Omega-3. These segments are mainly local produced functional products, imported ASEAN-content products, mostly from Thailand or small percentage from the developed countries such as Australia, USA or Europe (Stanton et al., 2011). Imports from developed countries are very small and can only be found in exclusive retailers because of its expensive prices. As functional products are highly diversified, market segments are very fragmented which makes it difficult to estimate the overall market size from market observations or trade estimates (Stanton et al., 2011).

Functional foods and drinks surface in the local market during 1990s when local producers and ASEAN-based multinational food companies competed to introduce new product lines to create new niches, capitalising on the emerging health trends at that time and market expansion (Stanton, Emms \& Sia, 2011). These companies include Nestlé, Danone, Unilever, Kellogg, and Quaker Oats. Today, healthy living is an increasingly important part of the food market and food marketing (Niva \& Makela, 2005). Table 4 lists some of commercial products available in the local markets.

Table 4. Local functional food products

\begin{tabular}{|c|c|c|c|}
\hline Types & Description & Brand & Producer \\
\hline \multirow[t]{3}{*}{ Probiotics } & Milk drink containing Lactobacillus casei Shirota & Yakult & Yakult Japan \\
\hline & & Nutrigen & $\begin{array}{l}\text { Mamee } \\
\text { Double-Decker }\end{array}$ \\
\hline & & Vitagen & Malaysia Milk \\
\hline Prebiotics & $\begin{array}{l}\text { Chocolate malt drink with oligosaccharide-fructo } \\
\text { and DHA/EPA }\end{array}$ & Oligo & $\begin{array}{l}\text { Power } \\
\text { (Malaysia) }\end{array}$ \\
\hline \multirow[t]{2}{*}{$\begin{array}{l}\text { Functional } \\
\text { Drink }\end{array}$} & Energy drink with "Kacip Fatimah" & $\begin{array}{l}\text { Per'l Kacip } \\
\text { Fatimah }\end{array}$ & $\begin{array}{l}\text { Power } \\
\text { (Malaysia) }\end{array}$ \\
\hline & Enriched sport drinks with vitamins & Gatorade & Permanis for Pepsico \\
\hline $\begin{array}{l}\text { Fortified } \\
\text { Drink }\end{array}$ & Orange juice contains dietary fibre and vitamins & $\begin{array}{l}\text { Sunkist } 100 \% \\
\text { Orange Juice }\end{array}$ & $\mathrm{F} \& \mathrm{~N}$ \\
\hline $\begin{array}{l}\text { Functional } \\
\text { Cereal }\end{array}$ & $\begin{array}{l}\text { Low fat whole grain breakfast cereal with minerals } \\
\text { and vitamins }\end{array}$ & Nestlé Fitnesse & Nestlé \\
\hline
\end{tabular}




\begin{tabular}{llll}
$\begin{array}{l}\text { Bakery } \\
\text { product }\end{array}$ & $\begin{array}{l}\text { Wholemeal bread with beta-glucan for cholesterol } \\
\text { lowering } \\
\text { Enriched range of crackers from high fibre, low } \\
\text { salt, oat-based }\end{array}$ & $\begin{array}{l}\text { Gardenia } \\
\text { "Breakthru" }\end{array}$ & Gardenia \\
Spread & $\begin{array}{l}\text { Cholesterols lowering spread made from olive oils, } \\
\text { contains vitamins and minerals }\end{array}$ & Naturel & Lam Soon \\
$\begin{array}{l}\text { Functional } \\
\text { Egg }\end{array}$ & $\begin{array}{l}\text { Chicken eggs contains Omega-3 and vitamins } \\
\text { Nutriplus }\end{array}$ & Nutriplus \\
\hline
\end{tabular}

Note: Information compiled through market observations from local hypermarkets and manufacturers' corporate websites.

\section{Demand for Functional Food in Malaysia}

According to Stanton et al. (2011), Malaysians tends to consume less processed food products than consumers of developed countries. An increasing trend towards consumption of processed foods is seen among young consumer group age below 40 years who seek convenience. These consumers are better educated, informed and receptive towards new products compared to older consumers. Furthermore, Stanton et al. (2011) also reveals in their findings that Malaysian consumers generally prefer the fortified version to regular product, if a choice was given, but only on the condition that the price difference between the products is not apparent and similar in quality. It is further revealed most Malaysian consumers are usually not aware they are purchasing functional foods, as functional foods are not labelled as "functional". Most functional products are not well differentiated and usually marketed as conventional foods and part of the wider marketing, advertising and market segmentation of manufacturers. Local functional products or imported ones are commonly distributed via retail channels. The distribution of functional food products uses similar strategy as conventional products. Table 5 lists the main retailers in Malaysia.

Table 5. Local distribution channels

\begin{tabular}{ll}
\hline Types & Retailers \\
\hline Hypermarkets & Giant (Dairy Farm International Group) \\
& Cold Storage (Dairy Farm International Group) \\
& Carrefour (Carrefour France) \\
& Tesco (UK-Malaysia joint venture) \\
& Mydin (local hypermarket) \\
& Econsave (local hypermarket) \\
Supermarkets & Jusco (AEON Group) \\
& The Store (local supermarket) \\
\hline
\end{tabular}

\section{Influencing Factors of Purchase Decisions}

Studies revealed that consumers in developed countries make purchase decision based on health reasons, are interested in healthy foods, and / or believe that foods can have health-promoting features (Niva \& Mäkelä, 2005). Quantitative research usually focus on attitudes towards specific products or product types, and aim to find out if type of products, tastes, added ingredients, health claims or any combinations of these would most appeal to consumers (Bech-Larsen \& Grunert, 2003; Urala \& Lähteenmäki, 2003). These studies indicated factors that could influence product acceptance includes price, healthiness, convenience, processing form and promised health effects (Niva \& Mäkelä, 2005).

Urala (2005) cites the most important criteria of functional foods' acceptance are perceived functional product characteristics such as naturalness and overall quality image. Concerns on the naturalness of functional foods often arise because the development of functional foods usually demands modern technology due to addition, removal or modification of ingredients (Urala, 2005). Consumers' reactions on the use of modern technology have also been studied. Jonas and Beckmann (1998) reveals that Danish respondents have negative opinions towards the fortification and modification of foods, and perceive such foods to be unnatural and impure; but further cites that the perceived naturalness of a functional food can vary across cultures.

Studies on health claims have shown there are tendency of consumers being distrustful to manufacturers' claims (West et al., 2002). According to Urala and Lähteenmäki (2007), safety of functional foods and consumers' 
suspicious attitude towards possible harmful effect of functional foods affects consumers' confidence in functional food, but the study also reveal mistrust may not affect personal behaviour, and consumers seem to be aware consuming functional foods may have risks and do not affect the willingness to use functional foods. Therefore, consumers' perception on functional food attributes is vital (Krystallis et al., 2008) and important indicator towards acceptance of the product.

The type of health-related information and the degree of trust in this information play an important role in acceptance of functional foods (Krystallis et al., 2008). According to Tuorila and Cardello (2002), information on health benefits of a food can increase the likelihood of its consumption. Consumers' knowledge also significantly influences the confidence in functional foods and eventually buying the product (Krystallis et al., 2008). Attitudes towards functional foods have been widely researched. It is found that belief in health effects or perceived benefits of functional foods is most crucial factor to purchase intention (Verbeke, 2005; Urala \& Lähteenmäki, 2004).

When comparing consumers across countries, Krutulyte et al. (2010) cites Americans and Japanese are accepting functional foods and consume as part of daily diets; Europeans are more critical when it comes to functional food consumptions; Danish consumers are sceptical towards functional foods. Finns seems to have a relatively trusting position on functional foods (Niva \& Mäkelä, 2005). In addition, attitudes to functional foods seem to be driven by a few factors: taste, healthiness, pleasure, security and familiarity (Urala \& Lähteenmäki, 2003). Urala (2005) cites important motive for consumption of functional foods is the personal motivation to engage in health preservation behaviour and the degree of consumer perception of functional foods. A study by van Kleef, van Trijp, and Luning (2005) reveals the relation between the consumer's health condition and a product's health claim could influence purchase intention. Further supported by Verbeke (2005) if there is an ailing family member presents or encounters a specific health problem, it will influence the acceptance of functional foods positively. However, Niva \& Mäkelä (2005) and Krystallis et al. (2008) cite that consumer health issues do not necessarily support the consumption functional foods, and the analyses of the relationship between health factors and the acceptance of functional foods are hard to find. Therefore, reasons behind the purchasing intention were different for different functional products (Urala \& Lähteenmäki, 2004, 2007).

Socio-demographics attributes such as age, gender and education are important factors that influence purchase intention (Krystallis et al., 2008). Many literature showed that female consumers are promising target group for functional foods than males because they display more interest in healthy food consumption and health in general (Bogue \& Ryan, 2000; Urala, 2005). Urala (2005) cites that consumer demographics characteristics are only partially correlated with the acceptance of functional foods. Verbeke (2005) further supported that consumer attitudes towards functional foods do not depend on their socio-demographics characteristics. It was found that consumers with the least education were more concerned and demanded stricter regulation on functional foods than those of higher education (Niva \& Mäkelä, 2005). Generally functional foods users are often more educated (Anttolainen, et al., 2001; de Jong, et al., 2003).

\section{Conclusion}

The study has gathered comprehensive information on functional foods, definitions of functional foods across different countries, as well as laws and regulatory bodies. The efforts aim to provide a clear view of functional food and its concept, and how it is perceived in other countries in comparison to Malaysia. The study has illustrated local consumers' pattern of frequently purchased processed foods and functional foods while providing insights into consumers' intention of consuming functional foods.

Previous studies of functional foods came mostly from developed countries such as Denmark, Finland, USA, etc. Difference exists between Western and Asian consumers. The consumption of functional foods is relative to individual's knowledge and attitude in health-related issues. Due to limited consumers' knowledge and awareness of functional ingredients and its health effects, the needs for accurate information and communication activities exist. In this area, marketers should provide honest and scientifically proven information and beneficial effects of functional foods. It is the government's role to provide reliable source of information to the public. The regulatory authorities should administer functional foods with highest integrity due to its ambiguous nature.

More research of local functional ingredients should be carried out and supported. Malaysia has a rich biodiversity of flora and fauna and can offer potential large sources of bioactive ingredients or variety of new functional foods (Tee, 2011). Collaborations between academics and industry will be significant for future research and development and growth of local functional foods (Tee, 2011). With this, trade opportunities and new lucrative segments would emerge for local industry and at global level. 


\section{References}

Agri-Food Trade Service. (2009). Consumer Trends: Functional Foods. Agriculture and Agri-Food Canada.

Alzamora, S. M., Salvatori, D., Tapia, S. M., Lopez-Malo, A., Welti-Chanes, J., \& Fito, P. (2005). Novel Functional Foods from Vegetable Matrices impregmated with Biologically Active Compounds. Journal of Food Engineering, 67, 205-214. http://dx.doi.org/10.1016/j.jfoodeng.2004.05.067

Anttolainen et al. (2001). Characteristics of users and nonusers of plant stanol ester margarine in Finland: An approach to study functional foods. Journal of the American Dietetic Association, 101, 1365-1368. http://dx.doi.org/10.1016/S0002-8223(01)00327-3

Arshad, F. (2002). Functional Foods from the Dietetic Perspective. Jurnal Kesihatan Masyarakat Isu Khas, 8-13.

Bech-Larsen, T., \& Grunert, K. G. (2003). The perceived healthiness of functional foods - A conjoint study of Danish, Finnish and American consumers' perception of functional foods. Appetite, 40, 9-14. http://dx.doi.org/10.1016/S0195-6663(02)00171-X

Bogue, J., \& Ryan, M. (2000). Market-oriented new product development: Functional foods and the Irish consumer. Agribusiness Discussion Paper 27. National University of Ireland, Cork: Department of food economics.

Broring, S., Cloutier, M. L., \& Leker, J. (2006). The front end of innovation in an era of industry convergence: evidence from nutraceuticals and functional foods. $R \&$ \& Management, 36,5 . http://dx.doi.org/10.1111/j.1467-9310.2006.00449.x

Brunsø, K., Grunert, K. G., \& Bredahl, L. (1996). An analysis of national and cross-national consumer segments using the food-related lifestyle instrument in Germany, France and Great Britain. MAPP Working paper.

Childs, N. M., \& Poryzees, G. H. (1997). Foods that help prevent disease: Consumer attitudes and public policy implications. British Food Journal, 9, 419-426.

CODEX Alimentarius. (2011). Retrieved December 14, 2011, from http://www.codexalimentarius.net

De Jong, N., Ocke', M. C., Branderhorst, H. A., \& Friele, R. (2003). Demographic and lifestyle characteristics of functional food consumers and dietary supplement users. British Journal of Nutrition, 89, 273-281. http://dx.doi.org/10.1079/BJN2002772

Diplock, A. T., Aggett, P. J., Ashwell, M., Bornet, F., Fern, E. B., \& Roberfroid, M. B. (1999). Scientific concepts of functional foods in Europe: Consensus document. British Journal of Nutrition, 81(11), 1-27.

Hobbs, J. E. (2002). Evolving supply chains in the nutraceuticals and functional foods industry. Canadian Journal of Agricultural Economics, 50, 559-568. http://dx.doi.org/10.1111/j.1744-7976.2002.tb00355.x

Jew, S., Vanstone, C. A., Antoine, J. M., \& Jones, P. J. H. (2008). Generic and product-specific health claim processes for functional foods across global jurisdictions. The Journal of Nutition, (Supplement), 1228-1236.

Jonas, M. S., \& Beckmann, S. C. (1998). Functional Foods: Consumer Perceptions in Denmark and England. MAPP working paper no.5.

Kim, J. Y., Kim, D. B., \& Lee, H. J. (2006). Regulations on health/functional foods in Korea. Toxicology, 221, 112-118. http://dx.doi.org/10.1016/j.tox.2006.01.016

Krutulyte et al. (2010). Perceived fit of different combinations of carriers and functional ingredients. Food Quality and Preference, 22, 11-16. Retrieved February 20, 2011, from ScienceDirect database. http://dx.doi.org/10.1016/j.foodqual.2010.06.001

Krystallis, A., Maglaras, G., \& Mamalis, S. (2008). Motivations and cognitive structures of consumers in their purchasing of functional foods. Food Quality and Preference, 19, 525-538. http://dx.doi.org/10.1016/j.foodqual.2007.12.005

Menrad, K. (2003). Market and marketing of functional food in Europe. Journal of Food Engineering, 56, 181-188. Retrieved February 20, 2011, from Science Direct database. http://dx.doi.org/10.1016/S0260-8774(02)00247-9

Ministry of Health. (2012). Guide to Classification of Food-Drug Interface Products. Retreived from http://fsq.moh.gov.my/v3/images/filepicker_users/5ec35272cb-78/Penerbitan/risalah/GuidetoFDIproducts.p $\mathrm{df}$ 
National Pharmaceutical Control Bureau. (2012). Retrieved January 31, 2012, from http://portal.bpfk.gov.my

Niva, M., \& Mäkelä, J. (2005). Finns and functional foods: socio-demographics, health efforts, notions of technology and the acceptability of health-promoting foods. International Journal of Consumer Studies.

Poulsen, J. B. (1999). Danish consumers' attitudes towards functional foods. Working paper 62, MAPP, The Arhus School of Business, Denmark.

Siro', I., Ka'polna, E., Ka'polna, B. T., \& Lugasi, A. (2008). Functional food. Product development, marketing and consumer. Appetite, 51, 456-467. Retrieved March 19, 2011, from ScienceDirect database. http://dx.doi.org/10.1016/j.appet.2008.05.060

Sloan, A. E. (2000). The top ten functional food trends. Food Technology, 54, 33-62.

Stanton, Emms, \& Sia. (2011). Malaysia's Market for Functional Foods, Nutraceuticals and Organic Foods. An Introduction for Canadian Producers and Exporters. Counsellor and Regional Agri-Food Trade Commissioner, South East Asia.

Tee, E. S. (2011). Functional foods health claims: The beneficial effects of functional foods must be scientifically substantiated. The Star, StarFit4Life - Diet \& Nutrition, p.11, 25 Dec 2011.

Tuorila, H., \& Cardello, A. V. (2002). Consumer responses to an off-flavor in juice in the presence of specific health claims. Food Quality and Preference, 13, 561-569. http://dx.doi.org/10.1016/S0950-3293(01)00076-3

Urala, N. (2005). Functional foods in Finland: Consumers' view, attitudes and willingness to use. VTT Publications.

Urala, N., \& Lähteenmäki, L. (2003). Reasons behind consumers functional food choices. pp. 33, $148-158$.

Urala, N., \& Lähteenmäki, L. (2004). Attitudes behind consumers' willingness to use functional foods. Food Quality and Preferences, 15, 793-803. http://dx.doi.org/10.1016/j.foodqual.2004.02.008

Urala, N., \& Lähteenmäki, L. (2007). Consumers' changing attitudes towards functional foods. Food Quality and Preference, 18, 1-12. http://dx.doi.org/10.1016/j.foodqual.2005.06.007

Van Kleef, W., Van Trijp, H. C., \& Luning, P. (2005). Functional foods: Health claim-food product compatibility and the impact of health claim framing on consumer evaluation. Appetite, 44, $299-308$. http://dx.doi.org/10.1016/j.appet.2005.01.009

Verbeke, W. (2005). Consumer acceptance of functional foods: socio-demographic, cognitive and attitudinal determinants. Food Quality and Preference, 45-47. http://dx.doi.org/10.1016/j.foodqual.2004.01.001

West, G. E., Gendron, C., Larue, B., \& Lambert, R. (2002). Consumers' valuation of functional properties of foods: results from a Canada-wide survey. Canadian Journal of Agricultural Economics, 50, 541-558. http://dx.doi.org/10.1111/j.1744-7976.2002.tb00354.x

Williamson, A. R., Hunt, A. E., Pope, J. F., \& Tolman, N. M. (2000). Recommendations of dietitians for overcoming barriers to dietary adherence in individuals with diabetes. The Diabetes Educator, 26, $272-278$. http://dx.doi.org/10.1177/014572170002600207

\section{Appendix 1. Definition of functional food across countries}

\begin{tabular}{lll}
\hline Countries & Definition of Functional Food & Source \\
\hline Japan & $\begin{array}{l}\text { Food for Specified Health Uses (FOSHU) refers to foods containing } \\
\text { ingredient with functions for health, and approved officially to } \\
\text { claim its physiological effects on the human body. }\end{array}$ & $\begin{array}{l}\text { Ministry of Health, } \\
\text { Labour and Welfare } \\
(2011)\end{array}$ \\
& FOSHU is intended to be consumed for the maintenance/promotion \\
& of health or special health uses by people who wish to control health \\
& conditions, including blood pressure or blood cholesterol. \\
& $\begin{array}{l}\text { Selling a food as FOSHU requires safety assessment, and the health } \\
\text { functions and claims of the food must be approved by the Ministry } \\
\end{array}$ & \\
& of Health, Labour and Welfare (MHLW). &
\end{tabular}


Canada A functional food is similar in appearance to, or may be, a conventional food that is consumed as part of a usual diet, and is demonstrated to have physiological benefits and/or reduce the risk of chronic disease beyond basic nutritional functions, i.e. they contain bioactive compound.

Europe

Functional foods have not been defined by legislation in Europe. Generally, they are considered as those foods which are intended to be consumed as part of the normal diet and contain biologically active components which offer the potential of enhanced health or reduced risk of disease.

Examples of functional foods include foods that contain specific minerals, vitamins, fatty acids or dietary fibre, foods with added biologically active substances such as phytochemicals or other antioxidants and probiotics that have live beneficial cultures.

Functional foods should be in the form of normal foods and they must demonstrate their effects in amounts that can normally be expected to be consumed in the diet.

A functional food can be a natural whole food, a food to which a component has been added, or a food from which a component has been removed by technological or biotechnological means.

It can also be a food in which the nature of one or more components has been modified, or a food in which the bioavailability of one or more components has been modified, or any combination of these possibilities.

A functional food may be targeted at the whole population or for particular groups, which may be defined, for example, by age or by genetic constitution.

USA Functional foods are designed to have physiological benefits and/or reduce the risk of chronic disease beyond basic nutritional functions, and may be similar in appearance to conventional food and consumed as part of regular diet.

National Center for Complementary and Alternative Medicine (NCCAM) interprets functional foods as components of the usual diet that may have biologically active components (e.g., polyphenols, phytoestrogens, fish oils, carotenoids) that may provide health benefits beyond basic nutrition.

However, functional foods are not defined as a regulatory product category, and products that NCCAM would interpret to be "functional foods" would either be foods or drugs to FDA, depending on the claims associated with the product.

Products that NCCAM would consider to be "functional foods" may be subject to FDA regulation as foods, dietary supplements, or drugs under the Act. The classification of a "functional food" under the Act is based on the product's intended use and may also involve other factors, depending on the elements of the statutory definition of a particular product category.
Agriculture \& Agri-Food

Canada (2009)

European Food

Information Council

(EUFIC), (2011)

European Commission

Concerted Action on

Functional Food Science

in Europe (FUFOSE),

coordinated by the

International Life

Sciences Institute (ILSI)

Europe, (2011)
United States of

Department of

Agriculture (USDA)

National Center for

Complementary and

Alternative Medicine

(NCCAM)

U.S. Department of

Health and Human

Services.

Food and Drug

Administration (FDA),

(2011) 


\begin{tabular}{|c|c|c|}
\hline \multirow[t]{3}{*}{$\begin{array}{l}\text { Australia } \\
\text { and New } \\
\text { Zealand }\end{array}$} & $\begin{array}{l}\text { Functional foods are not legally defined in Australia and New } \\
\text { Zealand. Policy guidance is being developed in this area currently, } \\
\text { and is treated as novel foods under the foods standards. }\end{array}$ & $\begin{array}{l}\text { Food Standards Australia } \\
\text { New Zealand (FSANZ), } \\
\text { (2011) }\end{array}$ \\
\hline & $\begin{array}{l}\text { Generally, functional foods are foods that bestow health benefits } \\
\text { beyond basic nutrition. Pre-market safety assessment by FSANZ is } \\
\text { required before functional foods can be sold to consumers in } \\
\text { Australia and New Zealand. }\end{array}$ & \\
\hline & $\begin{array}{l}\text { Novel foods are defined as non-traditional foods with no history of } \\
\text { safe use. The characteristics of a food that make it novel means } \\
\text { scientists cannot be certain they are safe to eat, so FSANZ assess } \\
\text { them thoroughly before they are allowed to be sold. }\end{array}$ & \\
\hline \multirow[t]{2}{*}{ Malaysia } & $\begin{array}{l}\text { There is no official definition for functional food. Due to the nature } \\
\text { of food-medicine interception, it is required by the Ministry of } \\
\text { Health to distinguish between a nutraceutical and functional food } \\
\text { product. }\end{array}$ & $\begin{array}{l}\text { National Pharmaceutical } \\
\text { Control Bureau (NPCB) }\end{array}$ \\
\hline & $\begin{array}{l}\text { Committee for the Classification of Food-Drug Interface Products } \\
\text { decides the category the product belongs and the authority involves. } \\
\text { Food Safety and Quality Division (FSQD) regulates functional } \\
\text { foods, while National Pharmaceutical Control Bureau (NPCB) } \\
\text { regulates nutraceuticals (Tee, 2007; Stanton et al., 2011). }\end{array}$ & $\begin{array}{l}\text { Ministry of Health } \\
\text { Malaysia (MOH), (2011) }\end{array}$ \\
\hline IFIC & $\begin{array}{l}\text { "Functional foods" are thought to provide benefits beyond basic } \\
\text { nutrition and may play a role in reducing or minimizing the risk of } \\
\text { certain diseases and other health conditions. Examples of these } \\
\text { foods include fruits and vegetables, whole grains, fortified foods } \\
\text { and beverages and some dietary supplements. }\end{array}$ & $\begin{array}{l}\text { International Food } \\
\text { Information Council } \\
\text { (IFIC), (2011) }\end{array}$ \\
\hline
\end{tabular}

